\title{
Valorization of lignin waste: High electrochemical capacitance of lignin-derived carbons in aqueous and ionic liquid electrolytes
}

\author{
Wantana Sangchoom, ${ }^{1}$ Darren A. Walsh ${ }^{1,2}$ and Robert Mokaya ${ }^{1, *}$ \\ ${ }^{1}$ School of Chemistry, University of Nottingham, University Park, Nottingham NG7 \\ 2RD, U. K. \\ ${ }^{2}$ GSK Carbon Neutral Laboratory for Sustainable Chemistry, University of \\ Nottingham, Jubilee Campus, Nottingham NG7 2TU, UK
}

E-mail: r.mokaya@nottingham.ac.uk(R.Mokaya) 


\begin{abstract}
This report describes the utilization of waste lignin-derived activated carbons (LACs) as high-energy/high-power electrode materials for electric double layer capacitors (EDLCs). The influence of carbon-pore structure on the capacitance of the LACs in two aqueous $\left(\mathrm{H}_{2} \mathrm{SO}_{4}\right.$ and $\left.\mathrm{KCl}\right)$ and two ionic liquid (1-ethyl-3-methylimidazolium ethylsulfate, $[\mathrm{EMIm}]\left[\mathrm{EtSO}_{4}\right]$, and 1-butyl-3-methylimidazolium tetrafluoroborate, [BMIm] $\left[\mathrm{BF}_{4}\right]$ ) electrolytes is evaluated. In EDLCs containing aqueous $\mathrm{H}_{2} \mathrm{SO}_{4}$ as electrolyte, the LACs exhibit specific capacitances of up to $223 \mathrm{~F} / \mathrm{g}$ and good cycling stability, with energy density of $5.0 \mathrm{Wh} / \mathrm{kg}$ at a power density of $200 \mathrm{~W} / \mathrm{kg}$. EDLCs containing $\mathrm{KCl}$ achieved a specific capacitance of $203 \mathrm{~F} / \mathrm{g}$, and energy density of $7.1 \mathrm{Wh} / \mathrm{kg}$ at a power density of $510 \mathrm{~W} / \mathrm{kg}$. The specific capacitances of the LACs in $[\mathrm{EMIm}]\left[\mathrm{EtSO}_{4}\right]$ and $[\mathrm{BMIm}]\left[\mathrm{BF}_{4}\right]$ were up to $147 \mathrm{~F} / \mathrm{g}$ and $175 \mathrm{~F} / \mathrm{g}$, respectively. The energy density in the IL electrolytes, is up to $25 \mathrm{Wh} / \mathrm{kg}$ at power density of $500 \mathrm{~W} / \mathrm{kg}$, and $16.4 \mathrm{Wh} / \mathrm{kg}$ at $15 \mathrm{~kW} / \mathrm{kg}$. We demonstrate that the electrochemical performance of the LACs depends not only the surface area and pore size, but also on the pore-wall thickness.
\end{abstract}




\section{Introduction}

Electrical energy is stored in supercapacitors by the reversible adsorption of ions from electrolyte solutions onto high-surface-area electrodes. ${ }^{1,2,3,4}$ Supercapacitors can be charged and discharged rapidly, ${ }^{5}$ but suffer the drawback of only being able to store relatively low amount of energy compared to batteries as charge is only stored at the surface of the electrode materials. ${ }^{1}$ Consequently, in recent decades, a number of studies have focused on the search for high-energy electrode materials for supercapacitors. ${ }^{6,7}$ The energy density of supercapacitors is given by $E=1 / 2 \mathrm{CV}^{2}$, where $C$ is capacitance, and $V$ is cell voltage. ${ }^{5,8} C$ can be increased by using high-surface-area electrode materials, such as nanostructured carbons and activated carbons (ACs), due to their large surface area, good electrical conductivity and low manufacturing costs. ${ }^{9,10,11}$ A particularly-attractive property of ACs is the ease with which their porosity can be tailored to target specific applications, including gas ${ }^{12}$ and energy ${ }^{13}$ storage and the fact that they can be synthesized from low-value waste materials, thus achieving valorisation. ${ }^{12-14}$

As well as increasing $C$, increasing the cell voltage, which depends on the electrochemical window of the electrolyte, can improve the energy and power density of supercapacitors. Aqueous electrolytes are highly conductive, have low viscosities, and can result in high specific capacitances, ${ }^{15,16,17}$ but their operating voltage is limited to about $1 \mathrm{~V}$, due to the decomposition of water at higher voltages. ${ }^{16,17}$ The use of organic electrolytes can increase the cell voltage to about $3 \mathrm{~V},{ }^{18,19,20}$ but their conductivity and achievable capacitance are relatively low compared to aqueous electrolytes. Recently, ionic liquids (ILs) have attracted interest as electrolytes for supercapacitors. ${ }^{21} \mathrm{ILs}$ have 
interesting properties, including inherent conductivity and wide electrochemical windows (over $3 \mathrm{~V}$ ), which could potentially result in the development of high-energy IL-based supercapacitors. $^{21,22}$

One of the most challenging tasks in supercapacitor electrode research is the search for the right material, and matching it to a suitable electrolyte to generate a combination of electrode material and electrolyte that can successfully maximize the energy and power of electrochemical devices. ${ }^{3,23-25}$ Herein, we describe the use of ACs derived from lignin waste as electrode materials. Lignin is an abundant natural and renewable raw material that is mainly generated as waste during the extraction of cellulose from woody precursors. Valorisation of lignin waste may be achieved by conversion to hydrochar via benign hydrothermal carbonisation processes, followed by activation to generate ligninderived activated carbons (LACs). ${ }^{26}$ We herein evaluate the specific capacitance, energy density and power density, rate capability, and durability of LAC-based electrodes in contact with aqueous $\left(\mathrm{H}_{2} \mathrm{SO}_{4}\right.$ and $\left.\mathrm{KCl}\right)$ and $\mathrm{IL}$ (1-ethyl-3-methylimidazolium ethylsulfate, [EMIm] $\left[\mathrm{EtSO}_{4}\right]$, and 1-butyl-3-methylimidazolium tetrafluoroborate, $\left.[\mathrm{BMIm}]\left[\mathrm{BF}_{4}\right]\right)$ electrolytes. The influence of carbon structure and porosity on the electrochemical properties of LACs was also evaluated, revealing insights into the role of the pore structure on the behavior of these novel carbons.

\section{Experimental section}

\subsection{Materials synthesis and porosity characterisation}

Hydrochar obtained from lignin waste via hydrothermal carbonization in high temperature water $\left(300{ }^{\circ} \mathrm{C}\right)$ was activated using established procedures. ${ }^{11,12}$ In brief, a 
mixture of hydrochar and $\mathrm{KOH}$ (at $\mathrm{KOH} /$ carbon ratio of 2 or 4) in an alumina boat was heated to between 600 and $900{ }^{\circ} \mathrm{C}$ (at ramp rate of $3{ }^{\circ} \mathrm{C} / \mathrm{min}$ ) under a flow of $\mathrm{N}_{2}$ in a horizontal tube furnace and the final temperature was held for $1 \mathrm{~h}$. The resulting carbonaceous matter was allowed to cool under a flow of $\mathrm{N}_{2}$, washed repeatedly with 1.0 $\mathrm{M} \mathrm{HCl}$ and distilled water at room temperature until the filtrate was at neutral $\mathrm{pH}$, and dried in an oven at $120{ }^{\circ} \mathrm{C}$. The ACs were designated as LACT:x, where $T$ is the activation temperature, and $x$ is the $\mathrm{KOH} /$ hydrochar weight ratio used during activation.

Elemental compositions of the carbons were determined using an Exeter Analytical CE-440 Elemental Analyser. Powder XRD analysis was performed using a Bruker D8 Advance powder diffractometer. XRD analysis was performed using $\mathrm{Cu} K_{\alpha}$ radiation $(\lambda=1.5406 \AA)$ and the instrument was operated at $40 \mathrm{kV}$ and $40 \mathrm{~mA}$, with step size and time of $0.02^{\circ}$ and $2 \mathrm{~s}$, respectively. A Horiba-Jobin-Yvon LabRAM Raman microscope (532 nm laser operating at ca. $4 \mathrm{~mW}(10 \%)$ and a 600 lines/mm grating was used to record Raman spectra. The spectra were averaged over 8 acquisitions of $60 \mathrm{~s}$ duration, while the Raman shift was calibrated using the Rayleigh peak and the 520.7 $\mathrm{cm}^{-1} \mathrm{Si}$ line from a Si (100) reference sample. Nitrogen-sorption isotherms were recorded using a Micrometrics ASAP 2020 sorptometer, after outgassing the samples under vacuum at $200{ }^{\circ} \mathrm{C}$ for $12 \mathrm{~h}$. The BET equation was applied for surface area calculation using adsorption data in the relative pressure $\left(\mathrm{P} / \mathrm{P}_{\mathrm{o}}\right)$ range $0.0-0.25$. The amount of nitrogen adsorbed at $\mathrm{P} / \mathrm{P}_{0} \sim 0.99$ was used to calculate the total pore volume. Micropore surface area and micropore volume were estimated by $t$-plot analysis, while pore size was 
obtained via a Non-Local Density Function Theory (NLDFT) method using nitrogen adsorption data.

\subsection{Electrode preparation}

Slurries containing $92 \mathrm{wt} \%$ of $\mathrm{AC}$ and $8 \mathrm{wt} \%$ of polytetrafluoroethylene, PTFE, binder were spread on polished glass-carbon current collectors to a loading of $4.3 \mathrm{mg} / \mathrm{cm}^{2}$. Symmetric supercapacitors were assembled by separating the AC-coated plates by a Nippon Kodoshi separator that had been soaked in electrolyte for about $10 \mathrm{~min}$. To prevent electrolyte loss during the course of the experiment, the sandwich electrode was wrapped with Paraffin film (Supporting Figure S1).

\subsection{Electrochemical measurements}

Electrochemical performances were determined using symmetric supercapacitors containing $2.0 \mathrm{M} \mathrm{H}_{2} \mathrm{SO}_{4}, 2.0 \mathrm{M} \mathrm{KCl}$, [BMIm] $\left[\mathrm{BF}_{4}\right]$, or $[\mathrm{EMIm}]\left[\mathrm{EtSO}_{4}\right]$ as electrolyte. Galvanostatic charge/discharge was performed at current loads between 0.5 and $10 \mathrm{~A} / \mathrm{g}$. Electrochemical impedance spectroscopy (EIS) measurements were performed in the frequency range $0.01 \mathrm{~Hz}-100 \mathrm{kHz}$ at $\mathrm{AC}$ amplitude of $5 \mathrm{mV}$. The cell was assembled and tested in ambient air at room temperature and allowed to equilibrate for $1 \mathrm{~h}$ before testing using a Model 760C Potentiostat (CH instruments Inc., Austin, TX). 


\section{Results and discussion}

\subsection{Structural and textural properties of Lignin-derived carbons}

The LACs prepared at a variety of temperature and $\mathrm{KOH} / \mathrm{Hydrochar}$ ratio were rich in elemental C (Supporting Table S1), and depending of the extent of activation, the C content was in the range of 68-93 wt\%, with the remainder consisting mainly of oxygen (7-31 wt $\%)$ and very small amounts of $\mathrm{H}(0.3-1.4 \mathrm{wt} \%)$. In general, the $\mathrm{C}$ content was greatest for samples prepared at high activation temperatures, while the converse was true for the $\mathrm{H}$ and $\mathrm{O}$ content. Thus, the $\mathrm{H} / \mathrm{C}$ and $\mathrm{O} / \mathrm{C}$ molar ratios were as low as 0.004 and 0.1 , respectively, for LACs activated at 800 and $900{ }^{\circ} \mathrm{C}$ (Table S1). Thermogravimetric analysis (TGA) indicated that almost no residual inorganic residues were present after thermal treatment in air (Supporting Figure S2). The chemical activation of the ligninderived hydrochar generated porous LACs (Supporting Figure S3 and S4) with a wide range of properties, ${ }^{26}$ which are summarized in Table 1 . Briefly, the LACs prepared at $\mathrm{KOH} /$ hydrochar ratio of 2 (LACT:2 series) were highly microporous (Figure S3) with pore sizes in the range 7-13 $\AA$, and surface areas and pore volumes of $1157-1924 \mathrm{~m}^{2} / \mathrm{g}$ and $0.59-0.95 \mathrm{~cm}^{3} / \mathrm{g}$, respectively. Moreover, the average pore wall thickness for this highly microporous series of LACs was in the range 5-8 $\AA$. The second series of LACs, prepared at $\mathrm{KOH} / \mathrm{Hydrochar}$ of 4 (LACT:4 series) were, after activation at $600{ }^{\circ} \mathrm{C}$, mainly microporous but contained a small proportion of mesopores (Figure S4). As the activation temperature rose up to $900{ }^{\circ} \mathrm{C}$, the pore size distribution (PSD) shifted to larger micropores and mesopores within the range 5-27 $\AA$ (Table 1). The LACT:4 series LACs had higher surface areas and pore volumes of $1820-3235 \mathrm{~m}^{2} / \mathrm{g}$ and $0.91-1.77 \mathrm{~cm}^{3} / \mathrm{g}$, 
respectively. Their average pore wall thickness was in the range 3-5 $\AA$ and, therefore, lower than for the LACT: 2 series LACs $(5-8 \AA)$. The differences in pore size and pore wall thickness were also evidenced by TEM analysis (Supporting Figure S5). The TEM images showed much thicker pore walls for sample LAC600:2 than for LAC800:4, while the pore size was smaller for the former. The level of pore order/disorder was similar, irrespective of level of activation.

Table 1. Textural properties of lignin-derived activated carbons (LAC) prepared at various temperatures and $\mathrm{KOH} / \mathrm{Hydrochar}$ ratio of 2 or 4 .

\begin{tabular}{l|l|l|l|l|l}
\hline Sample & $\begin{array}{l}\text { Surface area }^{\mathrm{a}} \\
\left(\mathrm{m}^{2} / \mathrm{g}\right)\end{array}$ & $\begin{array}{l}\text { Pore volume }^{\mathrm{b}} \\
\left(\mathrm{cm}^{3} / \mathrm{g}\right)\end{array}$ & $\begin{array}{l}\mathrm{S}_{\text {meso }}{ }^{\mathrm{c}} \\
\left(\mathrm{m}^{2} / \mathrm{g}\right)\end{array}$ & $\begin{array}{l}\text { Pore size }^{\mathrm{d}} \\
(\AA)\end{array}$ & $\begin{array}{l}\sigma_{\mathrm{w}}{ }^{\mathrm{e}} \\
(\AA)\end{array}$ \\
\hline LAC600:2 & $1157(1123)$ & $0.59(0.54)$ & 35 & $7 / 9 / 12$ & 7.8 \\
LAC700:2 & $1551(1502)$ & $0.77(0.72)$ & 49 & $7 / 9 / 12$ & 5.8 \\
LAC800:2 & $1924(1839)$ & $0.95(0.87)$ & 85 & $7 / 9 / 13$ & 4.7 \\
LAC600:4 & $1820(1627)$ & $0.91(0.75)$ & 193 & $6 / 8 / 11 / 20$ & 5.0 \\
LAC700:4 & $2038(1832)$ & $1.00(0.84)$ & 206 & $6 / 8 / 11 / 21$ & 4.5 \\
LAC800:4 & $3235(1978)$ & $1.77(0.93)$ & 1257 & $8 / 11 / 27$ & 2.2 \\
LAC900:4 & $2750(792)$ & $1.66(0.43)$ & 1958 & $5 / 8 / 11 / 27$ & 3.3 \\
\hline
\end{tabular}

The values in the parenthesis refer to the following: ${ }^{a}$ micropore surface area, ${ }^{b}$ micropore volume, ${ }^{\mathrm{c}}$ mesopore surface area obtained from; $\mathrm{S}_{\text {meso }}=\mathrm{S}_{\mathrm{BET}}-\mathrm{S}_{\text {micro }}$, ${ }^{\mathrm{d}}$ pore size distribution maxima obtained from NLDFT analysis, ${ }^{\mathrm{e}}$ pore wall thickness $=2 /\left(\rho \mathrm{S}_{\mathrm{BET}}\right)$, where $\rho=2.2$ $\mathrm{g} / \mathrm{cm}^{3}$ is density of carbon walls equated to the density of graphite. ${ }^{27,28}$

Powder XRD patterns of the LACs (Supporting Figure S6) exhibited two very broad peaks at $2 \theta=22^{\circ}$ and $43^{\circ}$, due to the (002) and (100) diffractions from graphitic 
domains. The peak at $2 \theta=43^{\circ}$ increased in magnitude upon activation at 800 and 900 ${ }^{\circ} \mathrm{C}$, presumably due to an increase in graphitization as the carbons were exposed to higher temperatures. However, the peaks remained very broad, which is an indication of the overall amorphous nature of the carbons. The amorphous nature of the carbons was also evidenced by Raman spectroscopy of the LACs (Supporting Figure S7), which revealed the D-peak (disordered carbon) at $1330-1350 \mathrm{~cm}^{-1}$ and G-peak (graphitic domains) at $1580-1595 \mathrm{~cm}^{-1}$. Using the two-band fitting model, the D-peak to G-peak intensity ratio $\left(\mathrm{I}_{\mathrm{D}} / \mathrm{I}_{\mathrm{G}}\right)$ was found to be in the range 0.87-0.98, with higher ratio for LACs activated at 800 and $900{ }^{\circ} \mathrm{C}$. Such an $\mathrm{I}_{\mathrm{D}} / \mathrm{I}_{\mathrm{G}}$ ratio is consistent with the LACs being predominantly amorphous.

\subsection{Electrochemical performance in aqueous electrolytes}

Figure 1 shows the cyclic voltammograms (CVs) of sample LAC800:4 over four different voltage windows in $2.0 \mathrm{M} \mathrm{H}_{2} \mathrm{SO}_{4}$ and $2.0 \mathrm{M} \mathrm{KCl}$, electrolytes that were selected due to the size of their ions and their high conductivity and low viscosity (Supporting Table S2). For both electrolytes, the shape of the CVs in the voltage range $0.0-1.0 \mathrm{~V}$ is highly rectangular, suggesting that the LAC electrodes could be used for supercapacitor applications. As the voltage increased to $1.2 \mathrm{~V}$ (especially in those responses recorded in the presence of $\mathrm{H}_{2} \mathrm{SO}_{4}$ ), the anodic current increased, indicating that some faradaic current was contributing to the total current. Nonetheless, comparison of Figures $1 \mathrm{~A}$ and 1B shows that the highest capacitive current flowed in $2.0 \mathrm{M} \mathrm{H}_{2} \mathrm{SO}_{4}$, resulting in the highest capacitance. 

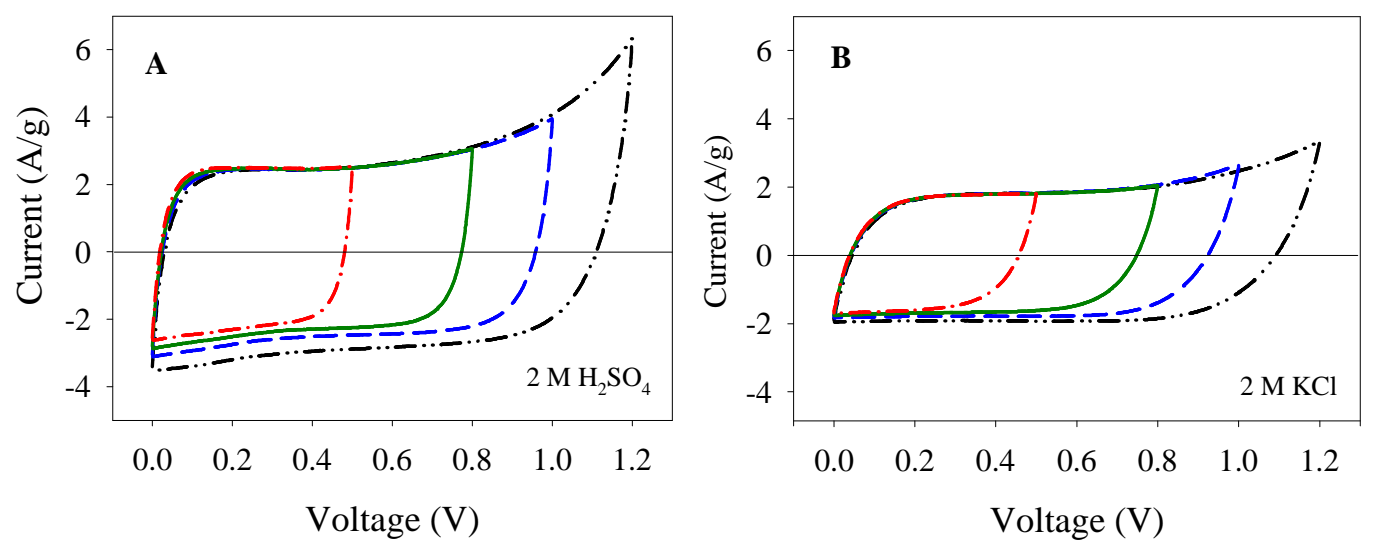

Figure 1. CVs recorded for sample LAC800:4 with symmetrical electrodes at scan rate of $100 \mathrm{mV} / \mathrm{s}$ operating at various voltage ranges in aqueous electrolytes; (A) $2.0 \mathrm{M}$ $\mathrm{H}_{2} \mathrm{SO}_{4}$, and (B) $2.0 \mathrm{M} \mathrm{KCl}$.

Galvanostatic charge/discharge analysis performed at $0.5 \mathrm{~A} / \mathrm{g}$ yielded triangular curves expected for predominantly capacitive response (Supporting Figure S8). ${ }^{29-31}$ The specific capacitances, $C_{\mathrm{sp}}$, of the various LACs were determined from the slope of the discharge curve using equation $1,32,33$ and are summarized in Table 2.

$$
\mathrm{C}_{\mathrm{sp}}=\frac{2 \cdot \mathrm{I}}{\mathrm{m} \cdot\left(\frac{\Delta \mathrm{V}}{\Delta \mathrm{t}}\right)}
$$

(Equation 1)

where $m$ is the mass of LAC on one electrode, $\Delta V / \Delta t$ is the slope of upper half of the discharge current after subtracting the IR drop and the factor 2 accounts for the use of two electrodes in series. 
Table 2. Specific capacitance of LAC samples obtained at a current of $0.5 \mathrm{~A} / \mathrm{g}$.

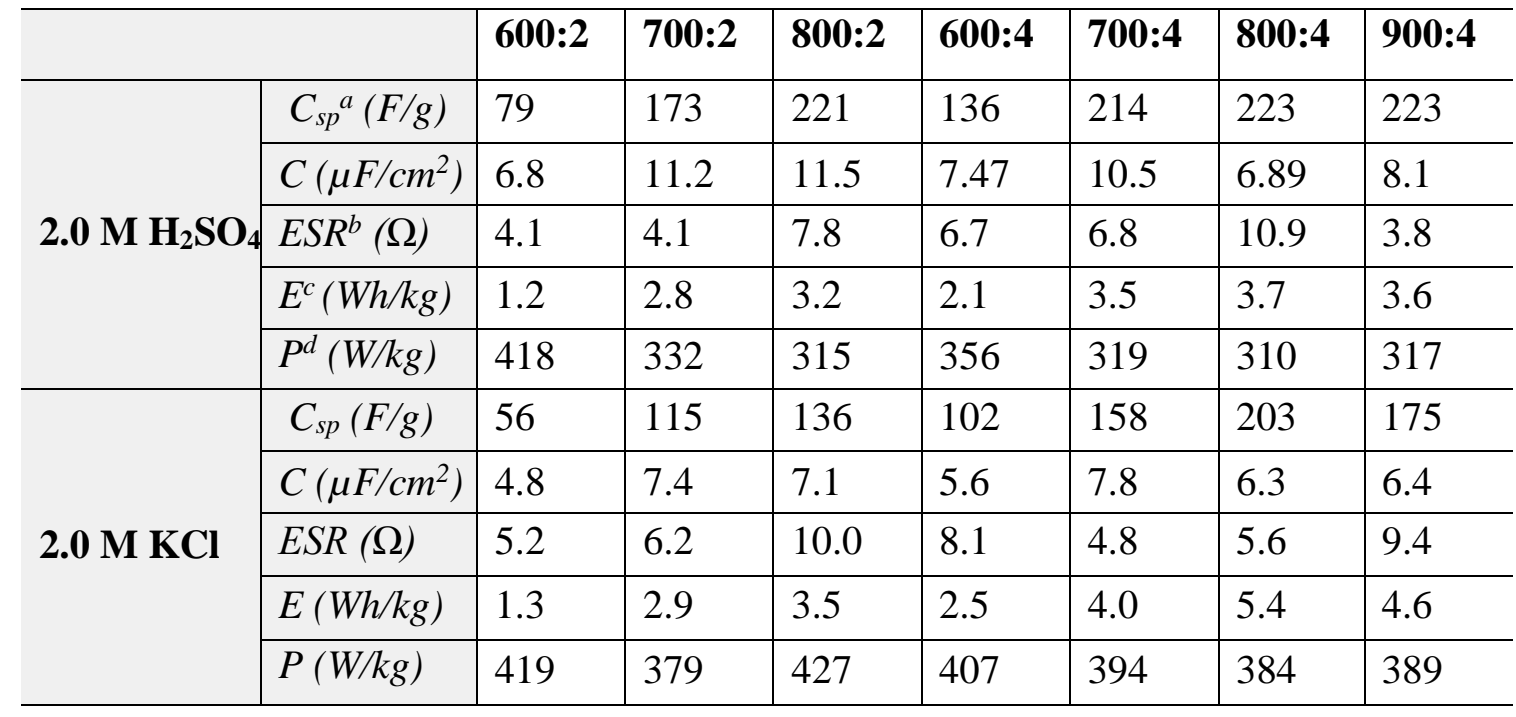

aThe specific capacitance obtained from the slope of the galvanostatic discharge curves at constant current of $0.5 \mathrm{~A} / \mathrm{g}$ according to equation $1 .{ }^{\mathrm{b}} \mathrm{ESR}$ value derived from the $\mathrm{x}-$ axis intercept from Nyquist impedance plot. ${ }^{\mathrm{c}, \mathrm{d}}$ The energy density and power density according to equation $E=1 / 2 \mathrm{CV}^{2}$ and $P=E / t$, where $E$ is energy density (Wh/kg), $C$ is specific capacitance $(\mathrm{F} / \mathrm{g}), V$ is the potential window $(\mathrm{V}), P$ is the power density $(\mathrm{W} / \mathrm{kg})$, and $t$ is the discharge time.

The highest $C_{\mathrm{sp}}$ values were obtained in $2.0 \mathrm{M} \mathrm{H}_{2} \mathrm{SO}_{4}(79-223 \mathrm{~F} / \mathrm{g})$. $C_{\mathrm{sp}}$ of LAC800:4 and LAC900:4 was $223 \mathrm{~F} / \mathrm{g}$, which is comparable to that of the best reported AC-based materials. ${ }^{34-37} C_{\mathrm{sp}}$ in $2.0 \mathrm{M} \mathrm{KCl}$ was in the range $56-175 \mathrm{~F} / \mathrm{g}$. Correlation of $C_{\mathrm{sp}}$ with the surface area of the LACs in each electrolyte (Supporting Figure S9) shows that the capacitance increased linearly with surface area up to about $2000 \mathrm{~m}^{2} / \mathrm{g}$, after which it reached a plateau. A similar phenomenon been observed previously, where $C_{\mathrm{sp}}$ saturation was apparent at surface areas of $1500 \mathrm{~m}^{2} / \mathrm{g}^{18}$ and $2500 \mathrm{~m}^{2} / \mathrm{g} .{ }^{38}$ Figure $\mathrm{S} 9$ also shows that the micropore surface area increased up to total surface area of ca. $2000 \mathrm{~m}^{2} / \mathrm{g}$, after which 
it reached a plateau. We note that $C_{\mathrm{sp}}$ of sample LAC800:4, which had the highest surface area of all LACs at $3235 \mathrm{~m}^{2} / \mathrm{g}$, was comparable to that of sample LAC800:2 despite the fact that the latter had half the surface area of the former. Although previous studies have reported that the specific capacitance of electrode materials relies on surface area, ${ }^{39,40}$ other factors such as microporosity, the nature of the electrolyte ions and mobility to active sites on the electrode may also play a role. ${ }^{41-45}$ In order to evaluate the surface area of LAC samples accessible to the electrolyte, we determined the surface capacitance $\left(\mathrm{C}_{\mathrm{s}}\right.$, $\mu F / \mathrm{cm}^{2}$ ) values (Supporting Figure S10). The relationship between the specific capacitance and the surface capacitance is well preserved for surface area below 2000 $\mathrm{m}^{2} / \mathrm{g}$, and at higher surface area, the surface capacitance decreases (Figure S10). The highest surface capacitance achieved was 11.49 and $7.75 \mu \mathrm{F} / \mathrm{cm}^{2}$ in $2 \mathrm{M} \mathrm{H}_{2} \mathrm{SO}_{4}$ and $2 \mathrm{M}$ $\mathrm{KCl}$, respectively. Moreover, it is observed that the most highly porous carbons i.e., samples LAC800:4 and LAC900:4, exhibited lower surface capacitance than expected. This suggests that the specific capacitance of electrodes is not just dependent on surface area only; other factors that govern accessibility of electrolyte species and mobility within electrode pore channels should also be considered. ${ }^{46,47}$

Barbieri et al. showed that $C_{\mathrm{sp}}$ of ACs decreased as the pore-wall thickness decreased, ${ }^{27}$ due to an increase in the screening length of electrical potential inside the pores. It is interesting to probe the link between the pore wall thickness of our LACs (especially those with surface areas above $2000 \mathrm{~m}^{2} / \mathrm{g}$ ). Assuming a slit-shaped pore model, Equation 2 was used to estimate the pore wall thickness, $\delta w$, of the LACs: ${ }^{28}$

$$
\delta_{w}=\frac{2}{\rho S_{B E T}}
$$


where $S_{B E T}$ is total surface area and $\rho=2.2 \mathrm{~g} / \mathrm{cm}^{3}$ is the density of pore walls (equated to graphite density). The pore-wall thicknesses are given in Table 1. The most microporous samples had thicker pore walls. In contrast, the most mesoporous carbons (LAC800:4 and LAC900:4), which were activated under the most severe conditions, had the thinnest pore walls and exhibit lower surface capacitance $\left(C_{\mathrm{s}}\right)$ values (Figure S10). Electrochemical impedance spectroscopy (EIS) was carried out in the frequency range $0.01 \mathrm{~Hz}-100 \mathrm{kHz}$ (Figure 2) and Nyquist plots showed intercepts on real-impedance axis at high frequencies, representing the equivalent series resistance (ESR), comprising the resistance of the electrolyte, the electrode, and the contact resistance at electrode/electrolyte interface. ${ }^{48,49}$ The presence of small semi-circle at high frequencies is due to the impedance at the electrolyte/electrode interface possibly representing redox reactivity of surface functionalities. ${ }^{50,51}$ The capacitive character of electrode is shown by the vertical line almost parallel to imaginary impedance axis, and the lines became more vertical as the activating temperature increased. The LACT:4 series in $\mathrm{H}_{2} \mathrm{SO}_{4}$ exhibited the most vertical lines at low frequency due to high conductivity of the electrolyte and large pore size that were conducive for charge accumulation. ESR was lowest for those cells containing $\mathrm{H}_{2} \mathrm{SO}_{4}$, due to the high conductivity of the electrolyte. Furthermore, lower ESR were obtained for LAC carbons with larger pores (LCAT:4 series) than for the LACT:2 series. Our findings agree with the work of Suss and co-workers ${ }^{52}$ who observed a decrease in resistance in large pore ACs. For LACs activated at low temperature (i.e., LAC600:2 and LAC600:4), there are large semi-circles, which were followed by a $45^{\circ}$ a Warburg impedance line, due to resistance in their narrow pores. 

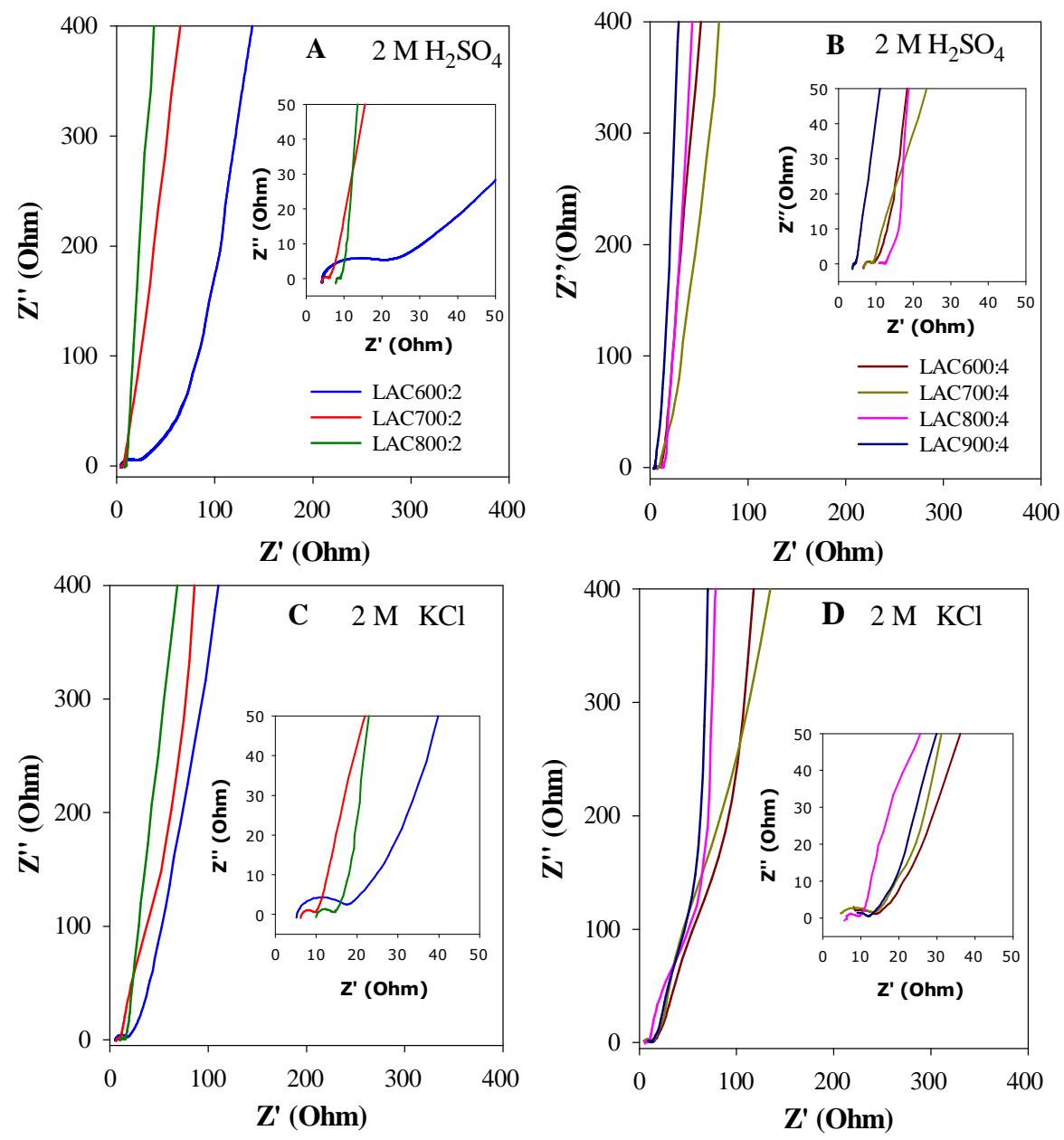

Figure 2. Nyquist impedance plots of LAC electrodes in: (A, B) $2.0 \mathrm{M} \mathrm{H}_{2} \mathrm{SO}_{4}$, and (C, D) $2.0 \mathrm{M} \mathrm{KCl}$, measured at frequency of $0.01 \mathrm{~Hz}-100 \mathrm{kHz}$. The insets show closeups of the high-frequency region in each case.

The resistance at the electrode/electrolyte interface can be evaluated by CV curves recorded at scan rate of $5 \mathrm{mV} / \mathrm{s}$ (Supporting Figure S11). CV curves of electrodes with high surface area exhibited almost ideal rectangular shapes indicating that their ESRs were low; generally, less distortion of CV curves and low ESR imply good accessibility of ions onto the electrode surface. It can be observed (Figure S11) that CV curves of LAC 
electrodes in $2 \mathrm{M} \mathrm{H}_{2} \mathrm{SO}_{4}$ and $2 \mathrm{M} \mathrm{KCl}$ display a good rectangular shape, which is consistent with expectations from previous results. ${ }^{53-55}$

Figure 3 (A and B) shows $C_{\mathrm{sp}}$ of LACs carbons as a function of the current load. For all electrolytes, there was a reduction in $C_{\mathrm{sp}}$ as the current increased, due to inaccessibility of the LACs to ions at high currents. The decrease in capacitance was especially significant at the highest current of $10 \mathrm{~A} / \mathrm{g}$, particularly for $2.0 \mathrm{M} \mathrm{KCl}$. In general, though, the LAC samples exhibited good performance at high current rate in the electrolytes. $\mathrm{In}_{2} \mathrm{SO}_{4}$, the highest specific capacitance of $223 \mathrm{~F} / \mathrm{g}$ at current load of 0.5 $\mathrm{A} / \mathrm{g}$ for sample LAC800:4 decreased to $174 \mathrm{~F} / \mathrm{g}$ at $10 \mathrm{~A} / \mathrm{g}$, representing $78 \%$ retention of the initial capacitance. Lower rate stability was observed in $\mathrm{KCl}$; for example, the specific capacitance of sample LAC800:4 in $\mathrm{KCl}$ was $203 \mathrm{~F} / \mathrm{g}$ at $0.5 \mathrm{~A} / \mathrm{g}$ and decreased to $102 \mathrm{~F} / \mathrm{g}$ at $10 \mathrm{~A} / \mathrm{g}$, representing $50 \%$ capacitance retention. The lower capacitance retention in $\mathrm{KCl}$ may be ascribed to lower ionic conductivity of the electrolyte. It is noteworthy that sample LAC800:4 exhibited the highest specific capacitance retention at high current load in all electrolytes due to mesoporous nature of this sample. ${ }^{56}$ Figure 3 (C and D) shows capacitance retention as a function of number of cycles during cyclic voltammetry at $100 \mathrm{mV} / \mathrm{s}$. The capacitance retention over 1000 cycles was $93-105 \%$ in $\mathrm{H}_{2} \mathrm{SO}_{4}$, and 73-100\% in KCl. The increase in capacitance for sample LAC800:2 in $\mathrm{H}_{2} \mathrm{SO}_{4}$ can be attributed to increased wetting of the pores of the LAC as cycling continued. The LAC carbons have good cycling stability over 1000 cycles in all three electrolytes, and the observed trend may be related to the capacitance stability in the respective electrolytes at high voltage. ${ }^{57}$ 

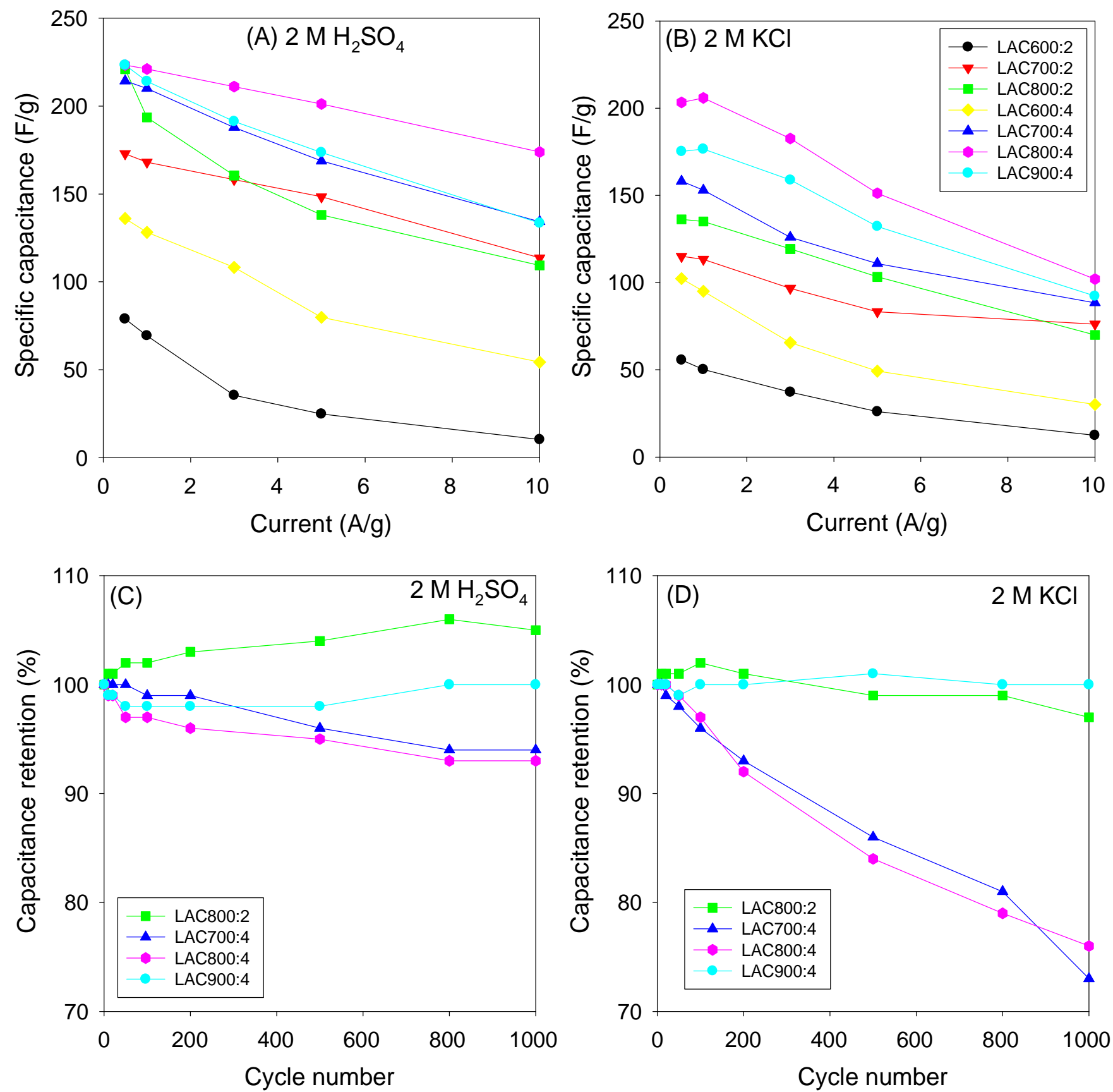

Figure 3. Specific capacitance as a function of discharge current load (A, B) and cycling performance at scan rate of $100 \mathrm{mV} / \mathrm{s}(\mathrm{C}, \mathrm{D})$ of LAC electrodes in $(\mathrm{A}, \mathrm{C}) 2 \mathrm{M}$ $\mathrm{H}_{2} \mathrm{SO}_{4}$ and (B, D) $2 \mathrm{M} \mathrm{KCl}$. 
Figure 4 shows the Ragone plot, wherein the energy density is plotted as a function of power density. The specific energy, $E_{\mathrm{sp}}$, and power, $P_{\mathrm{sp}}$, may be calculated from the galvanostatic charge/discharge curves at current load between 0.5 and $10 \mathrm{~A} / \mathrm{g}$ according to the equations; $E_{\mathrm{sp}}=1 / 8\left(\mathrm{C}_{\mathrm{sp}} \mathrm{V}^{2}\right)$ and $P_{\mathrm{sp}}=E_{\mathrm{sp}} / t$, where $t$ is the discharge time..$^{29,58,59}$ The LAC carbons have promising performance for both electrolytes. In $2 \mathrm{M} \mathrm{KCl}$, sample LAC800:4 achieved energy density of $7.1 \mathrm{Wh} / \mathrm{kg}$ at power density of $510 \mathrm{~W} / \mathrm{kg}$, and energy density of $3.5 \mathrm{Wh} / \mathrm{kg}$ at power density of $6.5 \mathrm{~kW} / \mathrm{kg}$ in a $1.0 \mathrm{~V}$ window voltage. The high energy density achieved in $2 \mathrm{M} \mathrm{KCl}$ is very attractive for an aqueous electrolyte taking into account the broader cell voltage compared to $2 \mathrm{M} \mathrm{H}_{2} \mathrm{SO}_{4}$. This energy density values are comparable to those reported for pure EDLC electrodes $(3.5-6.2 \mathrm{Wh} / \mathrm{kg}){ }^{60,61}$
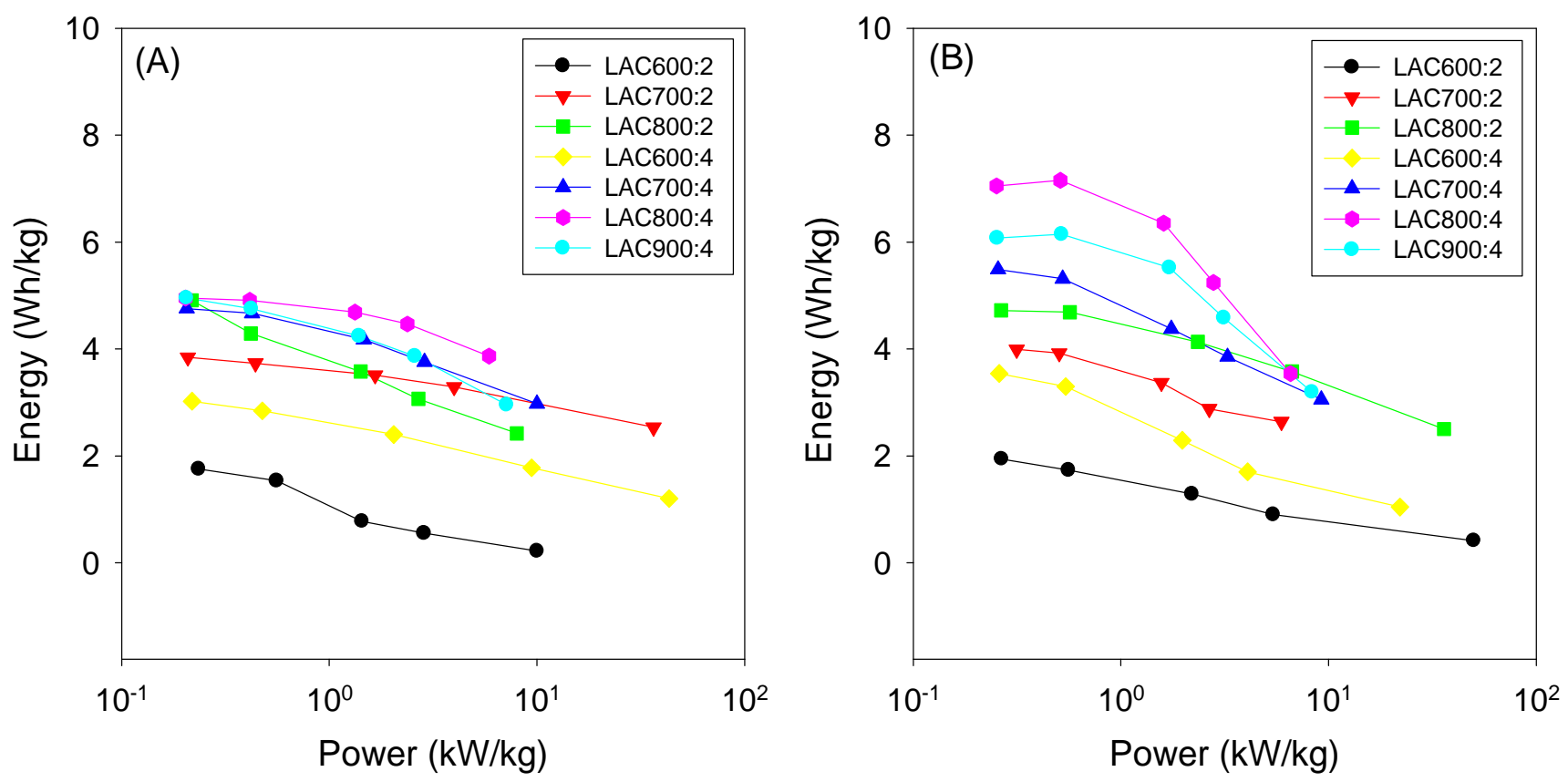

Figure 4. The Ragone plot of LAC electrodes measured at different current density in: (A) $2 \mathrm{M} \mathrm{H}_{2} \mathrm{SO}_{4}$, and (B) $2 \mathrm{M} \mathrm{KCl}$ electrolytes. 


\subsection{Electrochemical performance in ionic liquid electrolytes}

Figure 5A-C shows CVs recorded for sample $\mathrm{LAC} \mathrm{A00:4}$ using [EMIm]EtSO ${ }_{4}$ ] and $[\mathrm{BMIm}]\left[\mathrm{BF}_{4}\right]$ at $5 \mathrm{mV} / \mathrm{s}, 10 \mathrm{mV} / \mathrm{s}$, and $50 \mathrm{mV} / \mathrm{s}$. The $\mathrm{CVs}$ are nearly rectangular, as expected for purely capacitive behaviour. At $100 \mathrm{mV} / \mathrm{s}$ (Figure 5D), the $\mathrm{CV}$ curves are clearly distorted to oval shapes, due to the effects of resistance.
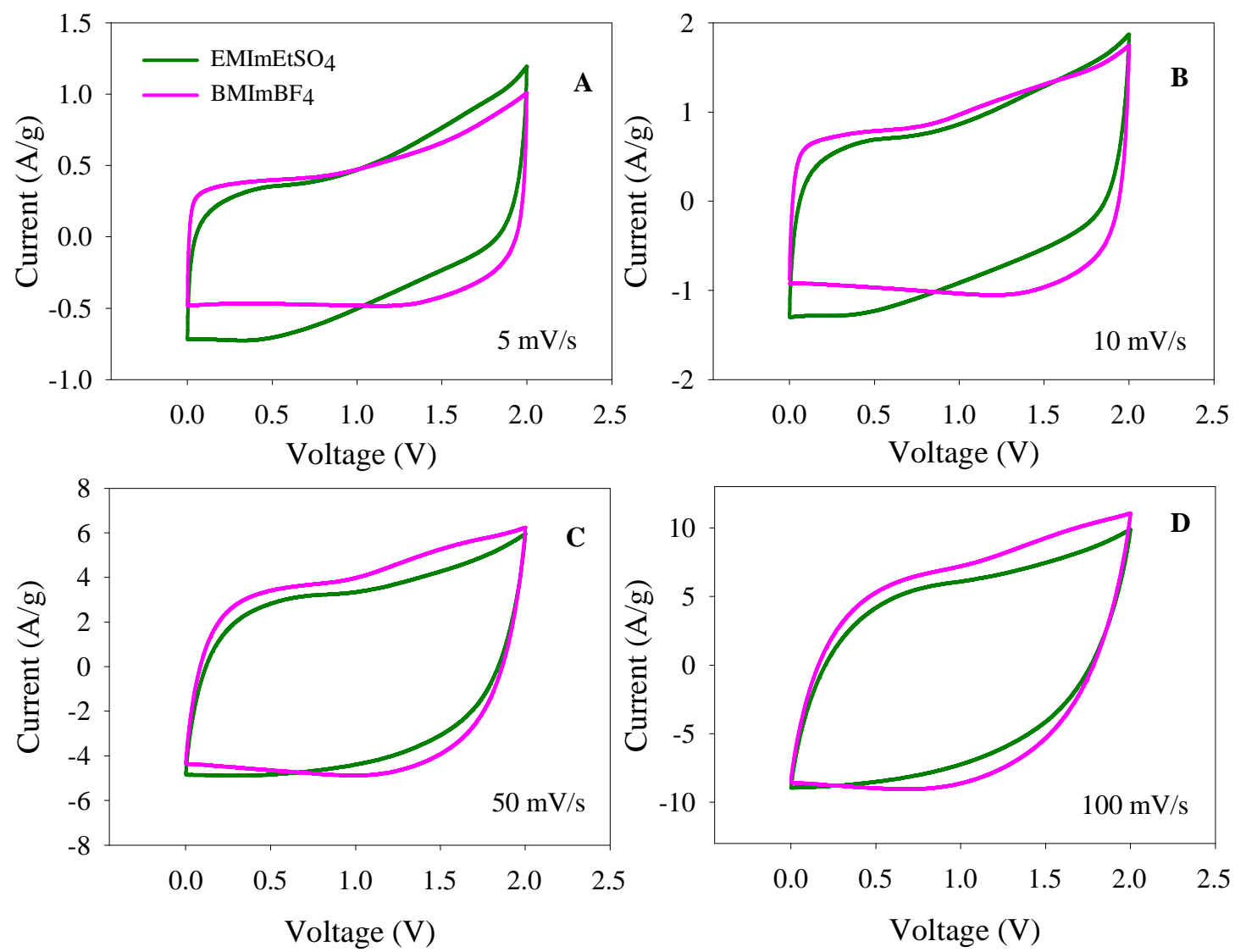

Figure 5. CV curves measured for sample LAC800:4 at various scan rates of (A) 5,

(B) 10 , (C) 50 and (D) $100 \mathrm{mV} / \mathrm{s}$ in ionic electrolytes.

Galvanostatic charge/discharge curves recorded at $0.5 \mathrm{~A} / \mathrm{g}$ (Supporting Figure

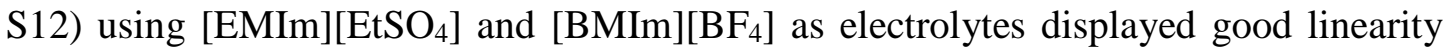


and reversibility, and low ohmic resistance. As the current increased to $3 \mathrm{~A} / \mathrm{g}$, the IR drop (inset Figure S12B) became more visible, ${ }^{47}$ particularly in $[\mathrm{EMIm}]\left[\mathrm{EtSO}_{4}\right]$. The capacitances of the LACs in the ILs was evaluated from the galvanostatic charge/discharge measurements, and Table 3 summarises the $C_{\mathrm{sp}}$ values. The LACs exhibit specific capacitance of between 6 and $147 \mathrm{~F} / \mathrm{g}$ and 12 to $175 \mathrm{~F} / \mathrm{g}$ in $\mathrm{EMImEtSO}_{4}$ and $\mathrm{BMImBF}_{4}$ electrolytes, respectively. LAC800:4, which had highest surface area of $3235 \mathrm{~m}^{2} / \mathrm{g}$ exhibited the highest specific capacitance of $175 \mathrm{~F} / \mathrm{g}$ at $0.5 \mathrm{~A} / \mathrm{g}$ in $[\mathrm{BMIm}]\left[\mathrm{BF}_{4}\right]$.

Table 3. Electrochemical capacitance of LACs obtained from galvanostatic discharge curves at constant current of $0.5 \mathrm{~A} / \mathrm{g}$ with $\mathrm{EMImEtSO}_{4}$ or $\mathrm{BMImBF}_{4}$ as electrolyte.

\begin{tabular}{|c|c|c|c|c|c|c|c|c|}
\hline & & $600: 2$ & $700: 2$ & 800:2 & 600:4 & 700:4 & $800: 4$ & 900:4 \\
\hline \multirow{5}{*}{$\begin{array}{l}{[\mathrm{EMIm}]} \\
{\left[\mathrm{EtSO}_{4}\right]}\end{array}$} & $\operatorname{Csp}(F / g)$ & 6 & 37 & 78 & 29 & 109 & 147 & 135 \\
\hline & $C\left(\mu F / \mathrm{cm}^{2}\right)$ & 0.52 & 2.39 & 4.1 & 1.6 & 5.4 & 4.5 & 4.9 \\
\hline & $\operatorname{ESR}(\Omega)^{a}$ & 153.1 & 74.1 & 42.0 & 48.4 & 17.7 & 24.0 & 104.3 \\
\hline & $E(W h / k g)$ & 0.4 & 2.6 & 7.0 & 2.9 & 11.9 & 14.9 & 13.4 \\
\hline & $P(W / k g)$ & 794 & 825 & 778 & 832 & 799 & 786 & 786 \\
\hline \multirow{5}{*}{$\begin{array}{l}{[\mathrm{BMIm}]} \\
{\left[\mathrm{BF}_{4}\right]}\end{array}$} & $\operatorname{Csp}(F / g)$ & 12 & 35 & 85 & 56 & 141 & 175 & 112 \\
\hline & $C\left(\mu F / c^{2}\right)$ & 1.04 & 2.3 & 4.4 & 3.1 & 6.9 & 5.4 & 4.07 \\
\hline & $\operatorname{ESR}(\Omega)^{a}$ & 132 & 98.3 & 78.1 & 49.8 & 24.8 & 30.5 & 79.8 \\
\hline & $E(W h / k g)$ & 0.6 & 2.0 & 7.1 & 5.4 & 13.2 & 18.8 & 11.3 \\
\hline & $P(W / k g)$ & 1014 & 846 & 794 & 810 & 855 & 781 & 809 \\
\hline
\end{tabular}

${ }^{a}$ The specific capacitance obtained from the slope of the galvanostatic discharge curves at the constant current of $0.5 \mathrm{~A} / \mathrm{g}$ according to equation $1 .{ }^{\mathrm{b}} \mathrm{ESR}$ value derived from the $\mathrm{X}$-axis intercept from Nyquist impedance plot, ${ }^{\mathrm{c}, \mathrm{d}}$ The energy density and power density value according to equation $E_{\mathrm{sp}}=1 / 8\left(\mathrm{CV}^{2}\right)$ and $P=E_{\mathrm{sp}} / t$, where $t$ is the discharge time. 
A comparison of specific capacitance and surface capacitance $\left(\mathrm{C}_{\mathrm{s}}\right)$ of LAC electrodes (Supporting Figure S13) reveals values of $1.04-6.92 \mu \mathrm{F} / \mathrm{cm}^{2}$ for $\mathrm{BMImBF}_{4}$, which is higher than that of $\mathrm{EMImEtSO}_{4}\left(0.52-5.35 \mu \mathrm{F} / \mathrm{cm}^{2}\right)$. This observation can be attributed to higher conductivity and lower density of $\mathrm{BMImBF}_{4}$ electrolyte resulting in higher diffusion of ions compared to $\mathrm{EMImEtSO}_{4}$. Nonetheless, noticeable specific capacitance saturation was observed for electrodes with high surface area. Similar to observation in aqueous electrolytes, the correlation between specific capacitance and surface area in the two ILs plateaued at surface area above $2000 \mathrm{~m}^{2} / \mathrm{g}$. Furthermore, the CVs of the cells containing [EMIm] $\left[\mathrm{EtSO}_{4}\right]$ exhibited a larger deviation from ideality compared to $[\mathrm{BMIm}]\left[\mathrm{BF}_{4}\right]$, with deviations also observed in the galvanostatic charge/discharge curves. This observation can be attributed to faster mass transport in $[\mathrm{BMIm}]\left[\mathrm{BF}_{4}\right]$. We explored the relationship between capacitance performance and pore size by correlating $C_{s p}$ in the two IL electrolytes with surface area or mesopore surface area (Supporting Figure S14); $C_{s p}$ of LACs with surface area above $2000 \mathrm{~m}^{2} / \mathrm{g}$ was much higher than that of samples with surface area below $2000 \mathrm{~m}^{2} / \mathrm{g}$. This can be related to the pore size distribution (Figure S3 and S4). As shown in Table 1, LACs with low surface area have a significant proportion of narrow micropores $(7-9 \AA)$ which are inaccessible to the IL ions $\left(7.8 \AA\right.$ and $9.7 \AA$ for biggest dimension of $[\mathrm{EMIm}]^{+}$and $[\mathrm{BMIm}]^{+}$, respectively) resulting in very low capacitance levels. On the other hand, LACs with high surface area (above $2000 \mathrm{~m}^{2} / \mathrm{g}$ ) have wider micropores $(10-20 \AA$ ) and narrow mesopores (20 - $30 \AA$ ), which are accessible to the large IL ions. This suggests that the presence of wider pores improves the specific capacitance of carbon electrodes in IL electrolytes. 
Hahn and co-workers ${ }^{62}$ suggested that very thin pore wall carbons cause potential drop inside the pores, which reduces the capacitance of carbon electrodes. They also suggested that at the electrode/electrolyte interface, the capacitive behavior is strongly influenced by the electronic properties of the solid rather than properties of the electrolyte solution. This suggestion is in agreement with the results from our experiments; the same phenomenon was observed for thin pore wall electrodes in both aqueous and IL electrolytes. As discussed earlier, the LACs prepared under extreme conditions (i.e., high activation temperature and $\mathrm{KOH} / \mathrm{hydrochar}$ ratio of 4 ) have high surface area and thin pore walls (Table 1) which cause capacitance saturation in supercapacitors especially for samples LAC800:4 and LAC900:4. ${ }^{27}$

Figure 6 (A and B) shows the $C_{s p}$ of LACs as a function of current load in the two

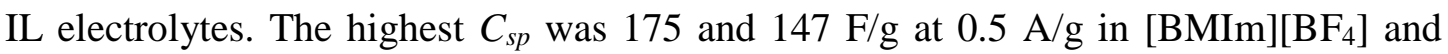
$\left[\right.$ EMIm] $\left[\mathrm{EtSO}_{4}\right]$, respectively. As expected, the $C_{s p}$ of all LACs reduced as current load increased from 0.5 to $10 \mathrm{~A} / \mathrm{g}$. The decline of $C_{s p}$ is significant at higher currents, especially for LACs with small pore size. It is noteworthy that sample LAC800:4 in [BMIm] $\left[\mathrm{BF}_{4}\right]$ achieved $C_{s p}$ of $118 \mathrm{~F} / \mathrm{g}$ at current load of $10 \mathrm{~A} / \mathrm{g}$, which is a very attractive value for supercapacitors in general. The decrease of $C_{s p}$ at higher current load can be ascribed to reduction in the level of accessibility of ions due to high resistance of the electrolytes and ion diffusion limitations within the carbon pore channels. At high currents, $C_{\mathrm{sp}}$ of LACs with larger pores (LACT:4 series) was higher than that for LACT:2 samples that possess smaller pores, which suggests that the high rate performance of LAC800:4 is due to high porosity, i.e., highest surface area and mesoporosity. ${ }^{56}$ 

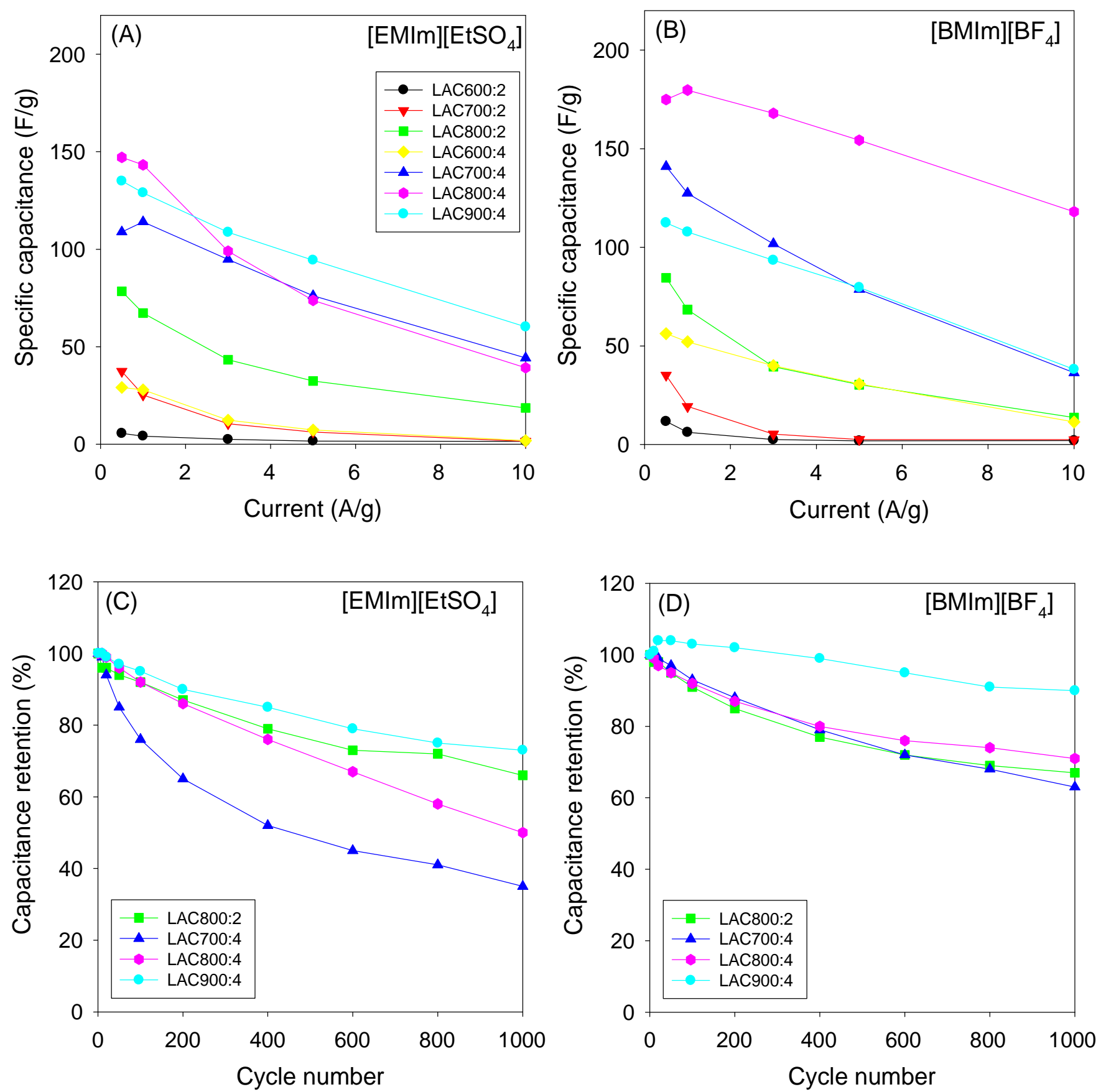

Figure 6. Specific capacitance as a function of discharge current load (A, B) and cycling performance obtained from $\mathrm{CV}$ at scan rate of $100 \mathrm{mV} / \mathrm{s}(\mathrm{C}, \mathrm{D})$ of LAC electrodes in $(\mathrm{A}, \mathrm{C})[\mathrm{EMIm}]\left[\mathrm{EtSO}_{4}\right]$ and $(\mathrm{B}, \mathrm{D})\left[\mathrm{BMIm}^{-}\left[\mathrm{BF}_{4}\right]\right.$. 
The stability of LACs in ILs was investigated by CV cycling at scan rate of 100 $\mathrm{mV} / \mathrm{s}$. Figure $6(\mathrm{C}$ and $\mathrm{D})$ shows the capacitance retention as a function of the number of cycles. The cycling stability in $[\mathrm{BMIm}]\left[\mathrm{BF}_{4}\right]$ was better than in $[\mathrm{EMIm}]\left[\mathrm{EtSO}_{4}\right]$. After 1000 cycles, the capacitance retention in $[\mathrm{BMIm}]\left[\mathrm{BF}_{4}\right]$ ranged between 64 and $90 \%$, whereas in $[\mathrm{EMIm}]\left[\mathrm{EtSO}_{4}\right]$ it was $35-73 \%$. The best cycling stability of $90 \%$ was observed for sample LAC800:4 in $[\mathrm{BMIm}]\left[\mathrm{BF}_{4}\right]$. This excellent retention performance can be related to the wider pores (larger micropores/small mesopores) of sample LAC800:4, which enables ready access to the active carbon surface.

The Nyquist plots of LACs in IL electrolytes measured in the frequency range of $0.01 \mathrm{~Hz}$ to $100 \mathrm{kHz}$ are shown in Figure 7. Since the ionic resistance of ILs is higher than that of aqueous electrolytes at room temperature, high ESR was observed. As the pore size of LACs increased, the ESR decreased and LACs with small pores exhibited a large semi-circle in their plots. As pore size of the LACs increased, the size of the semi-circle decreased indicating the minimising of charge transfer resistance. For both ILs, nonvertical lines were observed at low frequencies for LACs with small pores. As the pore size increased, the lines became more vertical, indicating that the capacitive behavior improved. In addition, for LACs in $[\mathrm{BMIm}]\left[\mathrm{BF}_{4}\right]$ showed more vertical capacitive lines in their Nyquist plots, indicating that the material was behaving more ideally than in $[\mathrm{EMIm}]\left[\mathrm{EtSO}_{4}\right]$. 

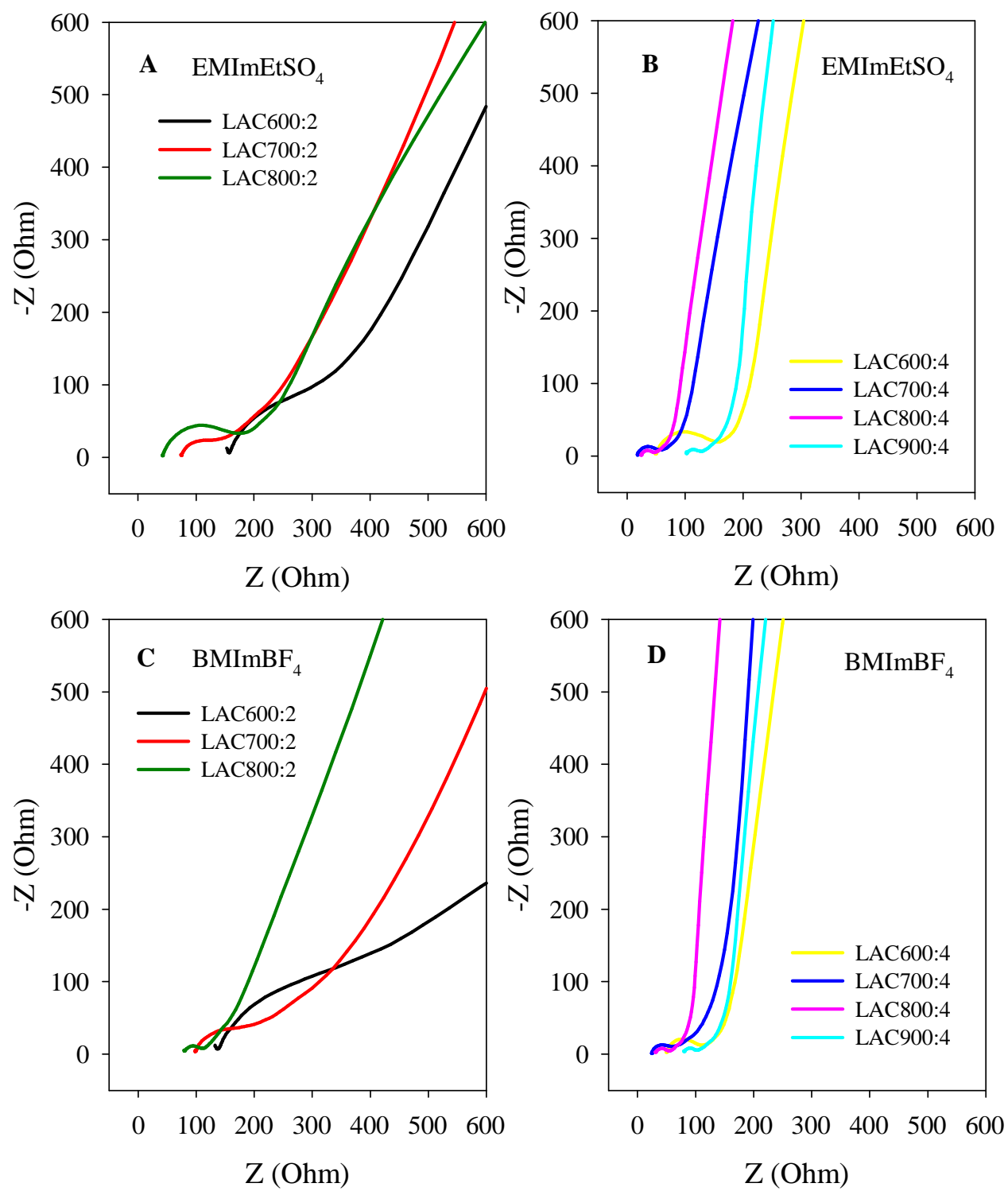

Figure 7. Nyquist impedance plot of LACs in (A, B) [EMIm] [EtSO 4 , and (C, D) $[\mathrm{BMIm}]\left[\mathrm{BF}_{4}\right]$ measured in the frequency range of $0.01 \mathrm{~Hz}-100 \mathrm{kHz}$.

A Ragone plot of energy density as a function of power density of electrodes is shown in Figure 8. Overall, the LACs showed high performance in IL electrolytes; over a $2.0 \mathrm{~V}$ window, sample LAC800:4 in $\left[\mathrm{BMIm}^{-}\left[\mathrm{BF}_{4}\right]\right.$ achieved energy density of 24.3 
$\mathrm{Wh} / \mathrm{kg}$ at a power density of $500 \mathrm{~W} / \mathrm{kg}$. At higher power of $15 \mathrm{~kW} / \mathrm{kg}$, the energy density remained high at $16.4 \mathrm{Wh} / \mathrm{kg}$. This result demonstrates the attractively high energy performance of supercapacitors derived from LAC electrodes in $[\mathrm{BMIm}]\left[\mathrm{BF}_{4}\right]$ electrolyte.
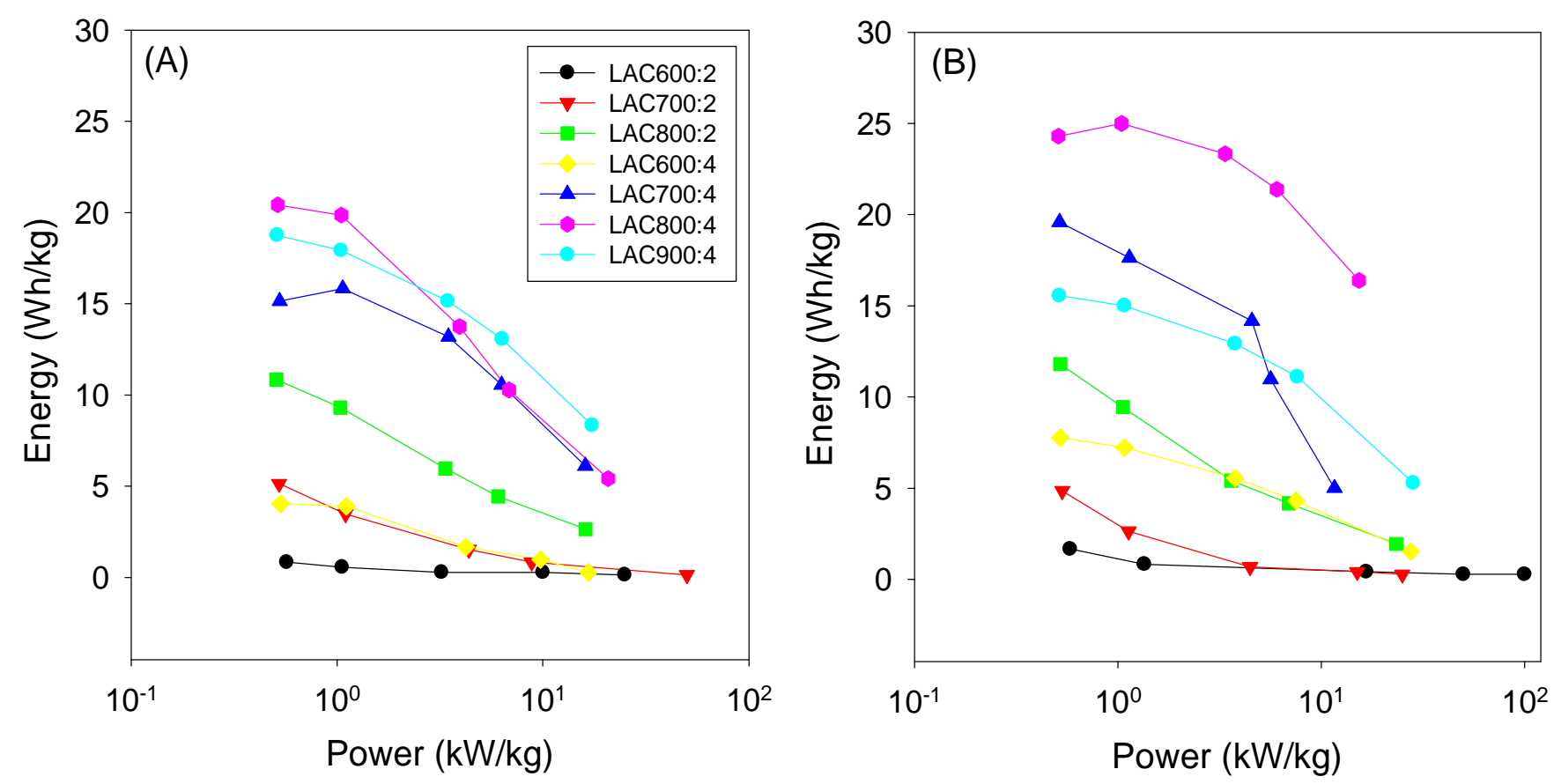

Figure 8. The Ragone plot of LAC electrodes measured at various current loads in: (A) $\mathrm{EMImEtSO}_{4}$ and (B) $\mathrm{BMImBF}_{4}$ electrolytes.

\section{Conclusion}

High performance electrode materials for EDLCs were fabricated from lignin-derived activated carbons (LACs). The influence of porous structure on electrochemical capacitive performance of LACs in aqueous and ionic liquid (IL) electrolytes has been evaluated. A high surface area carbon (sample LAC800:4) electrode in $2.0 \mathrm{M} \mathrm{H}_{2} \mathrm{SO}_{4}$ 
exhibits attractive capacitance of $223 \mathrm{~F} / \mathrm{g}$ and good cycling stability. Although the specific capacitance of the LAC electrodes in $2.0 \mathrm{M} \mathrm{KCl}$ was lower than in $\mathrm{H}_{2} \mathrm{SO}_{4}$, the former had higher energy density, which reached $7.1 \mathrm{Wh} / \mathrm{kg}$ at power density of $510 \mathrm{~W} / \mathrm{kg}$ due to a broad electrochemical window. In IL electrolytes, the specific capacitance achieved in $[\mathrm{EMIm}]\left[\mathrm{EtSO}_{4}\right]$ and $[\mathrm{BMIm}]\left[\mathrm{BF}_{4}\right]$ were up to $147 \mathrm{~F} / \mathrm{g}$ and $175 \mathrm{~F} / \mathrm{g}$, respectively. The energy density of LAC electrodes in IL electrolytes is exceptional and reaches 24.3 $\mathrm{Wh} / \mathrm{kg}$ at power density of $500 \mathrm{~W} / \mathrm{kg}$ for sample LAC800:4 in $\left[\mathrm{BMIm}\left[\mathrm{BF}_{4}\right]\right.$. High capacitances are achieved for carbon electrodes with high surface area but the capacitance is not directly proportional to increase of surface area especially above $2000 \mathrm{~m}^{2} / \mathrm{g}$.

\section{Acknowledgements}

We are grateful to the Rajamangala University of Technology Srivijaya (RMUTSV), Thailand for funding a studentship for WS.

\section{Supporting Information Available}

Three additional Tables and 15 Figures. 


\section{References}

1. B. Dunn, H. Kamath, J. M. Tarascon, Science, 2011, 334, 928-935.

2. J. R. Miller, P. Simon, Science, 2008, 321, 651-652.

3. E. Frackowiak and F. Béguin, Carbon, 2001, 39, 937-950.

4. P. Simon and Y. Gogotsi, Nat. Mater., 2008, 7, 845-854.

5. P. Simon and Y. Gogotsi, Acc. Chem. Res., 2012, 46, 1094-1103.

6. P. J. Hall, M. Mirzaeian, S. I. Fletcher, F. B. Sillars, A. J. R. Rennie, G. O. ShittaBey, G. Wilson, A. Cruden, R. Carter, Energy Environ. Sci., 2010, 3, 1238-1251.

7. K. Naoi, S. Ishimoto, J.-i. Miyamoto and W. Naoi, Energy Environ. Sci., 2012, 5, 9363-9373.

8. M. P. Bichat, E. Raymundo-Piñero and F. Béguin, Carbon, 2010, 48, 4351-4361.

9. X. Li and B. Wei, Nano Energy, 2013, 2, 159-173.

10. J. S. Bonso, G. D. Kalaw and J. P. Ferraris, J. Mater. Chem. A, 2014, 2, 418-424.

11. (a) M. Sevilla and R. Mokaya, Energy Environ. Sci., 2014, 7, 1250-1280; (b) J. C. Wang and S. Kaskel, J. Mater. Chem., 2012, 22, 23710-23725; (c) T. S. Blankenship II, N. Balahmar and R. Mokaya, Nat. Commun. 2017, 8, 1545; (d) T. S. Blankenship and R. Mokaya, Energy Environ. Sci., 2017, 10, 2552-2562 (e) E. Haffner-Staton, N. Balahmar and R. Mokaya, J. Mater. Chem. A 2016, 4, 13324- 13335.

12. (a) M. Sevilla, A. B. Fuertes and R. Mokaya, Energy Environ. Sci., 2011, 3, 14001410; (b) N. Balahmar, A. C. Mitchell, and R. Mokaya, Adv. Energy Mater., 2015, 5, 1500867 (c) H. M. Coromina, D. A. Walsh and R. Mokaya, J. Mater. Chem. A 2016, 4, 280-289. (d) M. Sevilla, W. Sangchoom, N. Balahmar, A. B. Fuertes and R. Mokaya, ACS Sust. Chem. Eng., 2016, 4, 4710-4716. (e) M. Cox and R. Mokaya, Sust. Energy Fuels, 2017, 1, 1414-1424.

13. (a) J. Niu, R. Shao, J. Liang, M. Dou, Z. Li, Y. Huang and F. Wang, Nano Energy, 2017, 36, 322-330; (b) J. Niu, J. Liang, R. Shao, M. Liu, M. Dou, Z. Lia, Y. Huang and F. Wang, Nano Energy, 2017, 41, 285-292. (c) R. Shao, J. Niu, J. Liang, M. Liu, Z. Zhang, M. Dou, Y. Huang and F. Wang, ACS Appl. Mater. Interfaces, 2017, 9, 42797-42805. 
14. (a) M. Sevilla, A. S. M. Al-Jumialy, A. B. Fuertes and R. Mokaya, ACS Appl. Mater. Interfaces, 2018, 10, 1623-1633; (b) B. Adeniran and R. Mokaya, Nano Energy, 2015, 16, 173-185.

15. (a) J. Huang, B. G. Sumpter and V. Meunier, Chem. Eur. J., 2008, 14, 6614-6626;

(b) K. Fic, G. Lota and E. Frackowiak, Electrochimica Acta, 2010, 55, 7484-7488;

(c) Q. T. Qu, B. Wang, L. C. Yang, Y. Shi, S. Tian and Y. P. Wu, Electrochem.Commun., 2008, 10, 1652-1655.

16. E. G. Calvo, F. Lufrano, P. Staiti, A. Brigandì, A. Arenillas and J. A. Menéndez, J. Power Sources, 2013, 241, 776-782.

17. M. D. Stoller, S. Park, Y. Zhu, J. An and R. S. Ruoff, Nano Letters, 2008, 8, 34983502 .

18. L. Wei, M. Sevilla, A. B. Fuertes, R. Mokaya and G. Yushin, Adv. Funct. Mater., 2012, 22, 827-834.

19. S. Pohlmann, B. Lobato, T. A. Centeno and A. Balducci, Phys. Chem. Chem. Phys., 2013, 15, 17287-17294.

20. B. Xu, S. Hou, H. Duan, G. Cao, M. Chu and Y. Yang, J. Power Sources, 2013, 228, 193-197. 
21. N. De Vos, C. Maton, and C. V. Steven, ChemElectroChem, 2014, 1, 1258-1270

22. M. Galinski, A. Lewandowski and S. I. Andrzej, Electrochimica Acta, 2006, 51, $5567-5580$

23. F. Béguin, V. Presser, A. Balducci and E. Frackowiak, Adv. Mater., 2014, 26, 22192251.

24. L. L. Zhang, Y. Gu and X. S. Zhao, J. Mater. Chem. A, 2013, 1, 9395-9408.

25. D. Qu and H. Shi, J. Power Sources, 1998, 74, 99-107.

26. W. Sangchoom and R. Mokaya, ACS Sust. Chem. Eng., 2015, 3, 1658-1667.

27. O. Barbieri, M. Hahn, A. Herzog and R. Kötz, Carbon, 2005, 43, 1303-1310.

28. A. Janes and E. Lust, ECS Transactions, 2008, 6, 269-278.

29. G. Z. Chen, Prog. Nat. Sci., 2013, 23, 245-255.

30. L. Demarconnay, E. Raymundo-Piñero and F. Béguin, Electrochem. Commun., 2010, 12, 1275-1278.

31. M. D. Stoller and R. S. Ruoff, Energy Environ. Sci., 2010, 3, 1294-1301.

32. Z. Zhou and X.-F. Wu, J. Power Sources, 2013, 222, 410-416.

33. H. Jin, X. Wang, Z. Gu and J. Polin, J. Power Sources, 2013, 236, 285-292.

34. S. Hu, S. Zhang, N. Pan and Y.-L. Hsieh, J. Power Sources, 2014, 270, 106-112.

35. A. B. Fuertes, F. Pico and J. M. Rojo, J. Power Sources, 2004, 133, 329-336.

36. C. Tran and V. Kalra, J. Power Sources, 2013, 235, 289-296.

37. L. Wei, M. Sevilla, A. B. Fuertes, R. Mokaya and G. Yushin, Adv. Energy Mater., 2011, 1, 356-361.

38. X. Zhang, X. Wang, L. Jiang, H. Wu, C. Wu and J. Su, J. Power Sources, 2012, 216, 290-296.

39. J. Gamby, P. L. Taberna, P. Simon, J. F. Fauvarque and M. Chesneau, J. Power Sources, 2001, 101, 109-116.

40. S. Vaquero, R. Díaz, M. Anderson, J. Palma and R. Marcilla, Electrochimica Acta, 2012, 86, 241-247.

41. M. Inagaki, H. Konno and O. Tanaike, J. Power Sources, 2010, 195, 7880-7903. 
42. E. Raymundo-Piñero, K. Kierzek, J. Machnikowski and F. Béguin, Carbon, 2006, 44, 2498-2507.

43. R. Mysyk, E. Raymundo-Piñero, J. Pernak and F. Béguin, J. Phys. Chem. C, 2009, 113, 13443-13449.

44. J.-G. Lee, J.-Y. Kim and S.-H. Kim, J. Power Sources, 2006, 160, 1495-1500.

45. H. M. Coromina, B. Adeniran, R. Mokaya and D. A. Walsh and, J. Mater. Chem. A, 2016, 4, 14586.

46. C.-x. Zhang, R. Zhang, B.-1. Xing, G. Cheng, Y.-b. Xie, W.-m. Qiao, L. Zhan, X.-y. Liang and L.-c. Ling, New Carbon Mater., 2010, 25, 129-133.

47. H. Wang, Q. Gao and J. Hu, Microporous Mesoporous Mater., 2010, 131, 89-96.

48. J. Jacquemin, P. Husson, A. A. H. Padua and V. Majer, Green Chem., 2006, 8, $172-$ 180.

49. J. Kang, J. Wen, S. H. Jayaram, A. Yu and X. Wang, Electrochimica Acta, 2014, 115, 587-598.

50. D. D. Macdonald, Electrochimica Acta, 2006, 51, 1376-1388.

51. M. D. Levi, C. Wang and D. Aurbach, J. Electroanal. Chem., 2004, 561, 1-11.

52. M. E. Suss, T. F. Baumann, M. A. Worsley, K. A. Rose, T. F. Jaramillo, M. Stadermann and J. G. Santiago, J. Power Sources, 2013, 241, 266-273.

53. L. Ren, D. Li and W. Qu, J. Colloid Interface Sci., 2001, 233, 12-22.

54. M. A. Azam, A. Fujiwara and T. Shimoda, Int. J. Electrochem. Sci., 2013, 8, 39023911.

55. Y. J.-W. T. Ying, X. Rong, Y. I. Bao-Lian, Acta Phys. Chim. Sin., 2011, 27, 479485.

56. T. Morishita, Y. Soneda, T. Tsumura and M. Inagaki, Carbon, 2006, 44, 2360-2367.

57. X. Sun, X. Zhang, H. Zhang, D. Zhang and Y. Ma, J. Solid State Electrochem., 2012, 16, 2597-2603.

58. X. Y. Chen, C. Chen, Z. J. Zhang, D. H. Xie, X. Deng and J. W. Liu, J. Power Sources, 2013, 230, 50-58.

59. A. Yu, V. Chabot and J. Zhang, Electrochemical Supercapacitors for Energy Storage and Delivery: Fundamentals and Applications, CRC Press, 2013. 
60. M. Sevilla, S. Álvarez, T. A. Centeno, A. B. Fuertes and F. Stoeckli, Electrochimica Acta, 2007, 52, 3207-3215.

61. X. He, P. Ling, J. Qiu, M. Yu, X. Zhang, C. Yu and M. Zheng, J. Power Sources, 2013, 240, 109-113.

62. M. Hahn, M. Baertschi, O. Barbieri, J.-C. Sauter, R. Kötz and R. Gallay, Electrochem. Solid-State Lett., 2004, 7, A33-A36. 


\section{Graphical Abstract}

Valorisation of waste lignin generates porous carbons with attractive properties as highenergy/high-power electrode materials for electric double layer capacitors (EDLCs); achieving energy density of $25 \mathrm{Wh} / \mathrm{kg}$ at power density of $500 \mathrm{~W} / \mathrm{kg}$ in ionic liquid electrolytes.
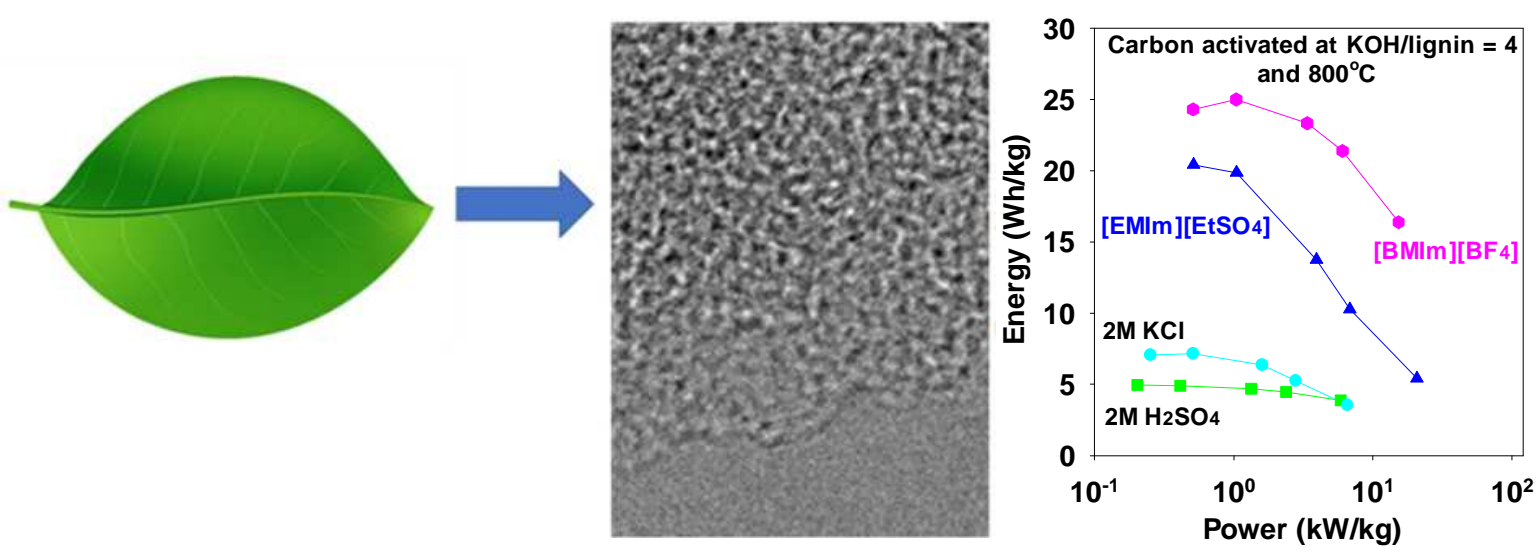